\title{
Interpolation methods for thematic maps of soybean yield and soil chemical attributes
}

\section{Métodos de interpolação para mapas temáticos de produtividade da soja e atributos químicos do solo}

\author{
Nelson Miguel Betzek ${ }^{1}$; Eduardo Godoy de Souza ${ }^{2 *}$; Claudio Leones Bazzi; \\ Ricardo Sobjak; ${ }^{4}$ Vanderlei Artur Bier ${ }^{5}$; Erivelto Mercante ${ }^{6}$
}

\begin{abstract}
The application of precision agriculture considers the values of non-sampled places by the interpolation of sample data. The accuracy with which the maps of spatial distribution of yield and the soil attributes are produced in the interpolation process influences their application and utilization. This paper aimed to compare three interpolation methods (inverse of the distance, inverse of the square distance, and ordinary kriging) in the construction of thematic maps of soybean yield and soil chemical attributes. A set of data referred to 55 sampling units for the construction maps of soybean yield and of eight soil chemical attributes, by different interpolation methods. The comparison was made based on the error matrix, by calculating the Kappa and Tau indices, beyond the relative deviation coefficient (RDC). It was noticed that the inverse of the square distance was the interpolator that less influenced the data behavior, and the best interpolation method dependent of the variability of the studied attribute. The kriging and the inverse of the square distance were considered the methods that presented the best results in the interpolation of data.
\end{abstract}

Key words: Geostatistics. Precision agriculture. Spatial variability.

\section{Resumo}

A aplicação da agricultura de precisão considera os valores mensurados para lugares não amostrados obtidos por meio da interpolação dos dados amostrais. A precisão com que os mapas de distribuição espacial da produtividade e atributos do solo são produzidos no processo de interpolação influencia a sua aplicação e utilização. Assim, este trabalho teve como objetivo comparar três métodos de interpolação (inverso da distância, inverso do quadrado da distância e krigagem ordinária) na construção de mapas temáticos de produtividade de soja e atributos químicos do solo. Um conjunto de dados referentes a 55 unidades de amostragem foi utilizado para a construção dos mapas de oito atributos químicos do solo e da produtividade de soja, por diferentes métodos de interpolação. A comparação foi feita com base na matriz de erro, por meio do cálculo dos índices Kappa e Tau, além do coeficiente de desvio relativo

\footnotetext{
${ }^{1}$ Prof. M.e, Departamento de Computação, Universidade Tecnológica Federal do Paraná, UTFPR, Medianeira, PR, Brasil. Doutorando do Programa de Pós-Graduação em Engenharia Agrícola, Universidade Estadual do Oeste do Paraná, PGEAGRI/ UNIOESTE, Cascavel, PR, Brasil. E-mail: nmbetzek@utfpr.edu.br

2 Eng $^{\circ}$ Mecânico, Prof. Dr, Associado, UNIOESTE/CASCAVEL/CCET/PGEAGRI/SBA, Grupos de Pesquisa GROSAP e GGEA, Pesquisador de Produtividade do CNPq. Cascavel, PR, Brasil.E-mail: eduardo.souza@unioeste.br

3 Prof. Dr. Adjunto, Departamento de Computação, UTFPR, Medianeira, PR, Brasil. E-mail: bazzi@utfpr.edu.br

${ }^{4}$ Prof. M.e, Departamento de Computação, UTFPR, Medianeira, PR, Brasil. E-mail: sobjak@utfpr.edu.br

${ }^{5}$ Eng $^{\circ}$ Agrícola, Prof. M.e, UNIOESTE, Cascavel, PR, Brasil. E-mail: vabier@hotmail.com

${ }^{6}$ Eng $^{\circ}$ Agrícola, Prof. Dr. Associado, UNIOESTE/Cascavel/CCET/PGEAGRI/SBA, Grupos de pesquisa GROSAP e GGEA, Pesquisador Produtividade CNPq. Cascavel, PR, Brasil. E-mail: erivelto.mercante@unioeste.br

* Author for correspondence
} 
(CDR). Verificou-se que o interpolador inverso do quadrado da distância foi o que menos influenciou o comportamento dos dados, e que o melhor método de interpolação depende da variabilidade do atributo estudado. A krigagem e o inverso do quadrado da distância foram considerados os métodos que apresentaram melhores resultados na interpolação de dados.

Palavras-chave: Agricultura de precisão. Geoestatística. Variedade espacial.

The spatial variability of soil properties can be influenced by the complexity of the factors related to its composition, such as climate, parent material, relief, organic structure, and time (intrinsic factors); as well as management activities such as soil preparation, fertilization, and crop rotation (extrinsic factors) (DAVATGAR et al., 2012; SILVA NETO et al., 2011; CORRÊA et al., 2009). According to Doerge (2000), agronomically speaking, it makes sense to apply nutrients and other agricultural inputs at different rates in heterogeneous fields. This variation in the application must meet the local needs of the soil, and also take into account the economic and environmental aspects. The technology that applies agricultural inputs in a localized form and at the correct moment is called precision agriculture (PA). PA makes use of thematic maps built with results of a laboratory analysis of the soil's physical and chemical attributes and also of the yield in which it is considered the sample position (AUBERT et al., 2012). These maps show the spatial variability of an attribute in a particular area of analysis and are generated according to the interpolated data.

The accuracy of these maps is a very important factor in PA utilization. The interpolated methods used can influence the estimated values and, consequently, the construction of these maps. The most commonly used methods in PA use inverse distance to a power (IDP) and the kriging for interpolation (BABAK; DEUTSCH, 2009). The accuracy with which the values are measured by interpolation can be certificated by the Kappa coefficients (COHEN, 1960), Tau (MA; REDMOND, 1995), and RDC (COELHO et al., 2009). Kappa and Tau were also used by Souza et al. (2013); Faria et al. (2014); Guedes et al. (2013) and they are quantitative methods in which the values needs to be reclassified in equal classes. To do so, the values are computed in an error matrix, and all the elements of this matrix are considered to give the desired index (SANO et al., 2009). On the other side, the relative deviation coefficient (RDC) calculates the medium difference in module of the interpolated values in each map, considering one of them as a standard, and expresses the result in percentage. This method was also used by Souza et al. (2016); and Suszek et al. (2011). This paper aimed to compare three interpolation methods (inverse of the distance, inverse of the square distance, and ordinary kriging) in the construction of thematic maps in an area cultivated with soybeans.

The data related to the yield of soybean and soil chemical attributes in this experiment were collected in an agricultural property located in a field of 19.6 ha, in the municipality of Cascavel, state of Paraná, with the geographical center at 2457'19'S, $53^{\circ} 33^{\prime} 60^{\prime \prime} \mathrm{W}$, and a medium elevation of $706 \mathrm{~m}$ of altitude. This area has been cultivated by a notillage system for over ten years, with a rotation of soybean, corn, and oat crops. During this period, soil chemical analysis and corrections of limestone and fertilization with nitrogen, phosphorus, and potassium were made according to technical recommendations using uniform rate technology.

The sample grid was composed of 55 points that were defined as being located next to the central imaginary line of each of the four level curves (Figure 1), with a distance alternating between 20, 40 and $60 \mathrm{~m}$. The collection of the yield samples was made manually, with each sample point represented by an area of approximately $0.9 \mathrm{~m}^{2}$. From the sample point, two lines were harvested in a route of $1.0 \mathrm{~m}$, with $0.45 \mathrm{~m}$ of spacing between lines. Eight 
soil samples were collected at each point, with the help of a manual auger, in the layer $0-0.20 \mathrm{~m}$ and in a radius of $3 \mathrm{~m}$ from the point determined by the sample grid (adapted from WOLLENHAUPT; WOLKOWSKI, 1994). The following chemical attributes were analyzed: potassium $(\mathrm{K})$, calcium $(\mathrm{Ca})$, magnesium $(\mathrm{Mg})$, copper $(\mathrm{Cu})$, iron $(\mathrm{Fe})$, manganese $(\mathrm{Mn})$, carbon $(\mathrm{C})$, and $\mathrm{pH}$.

The sample data were submitted to the exploratory analysis, aiming to identify discrepant points, as well to visualize the distribution of the spatial data according to the sample grid, which was represented by the inter-quartile classification. In the descriptive data analysis, the position, dispersion, and distribution form measurements were calculated. The coefficient of variation (CV) was classified as low when $\mathrm{CV} \leq 10 \%$, medium when $10 \%<\mathrm{CV} \leq 20 \%$, high when $20 \%<\mathrm{CV} \leq 30 \%$, and very high when $\mathrm{CV}>30 \%$ (PIMENTEL-GOMES, 2009). To verify the data normality, a KolmogorovSmirnovs test was applied to the level of $5 \%$ significance.

Figure 1. Sketch of the experiment sample grid.

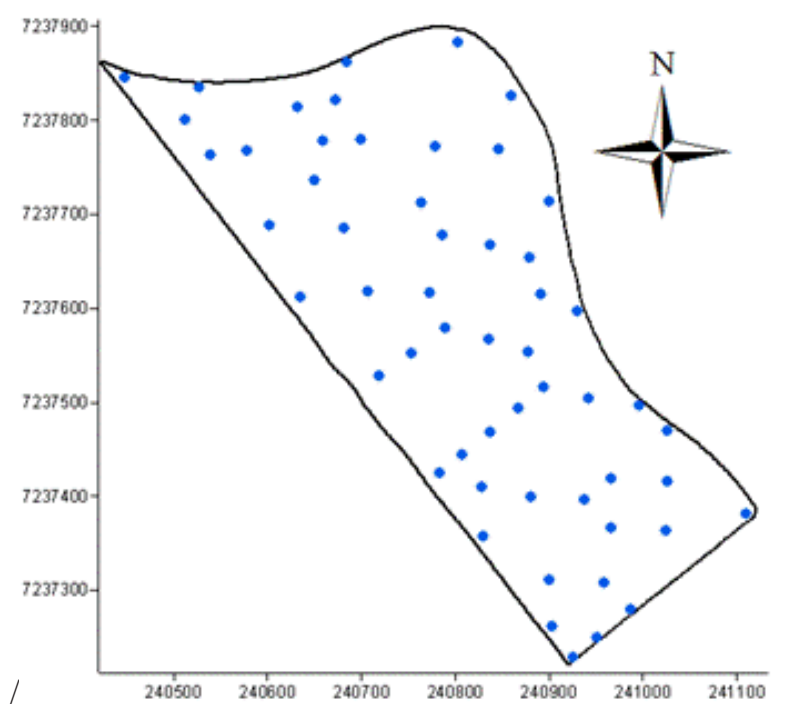

The data were analyzed spatially using geostatistics (software ArcView 9.2), with the semivariance calculated by using the Matheron classical estimator. The number of 55 sample points was enough to provide more than 30 pairs in each semivariance, as recommended by Journell and Huijbregts (1978). The spatial dependence degree of the semivariograms was assessed by the spatial dependency index (SDI, Equation 1), which was classified according to Cambardella et al. (1994): SDI $\leq 25 \%$ - strong spatial dependence, $25 \% \leq \mathrm{SDI} \leq 75 \%$ - moderate spatial dependence, and SDI $\geq 75 \%$ - weak spatial dependence.

$$
\mathrm{SDI}=\frac{\mathrm{C}_{0}}{\mathrm{C}_{0}+\mathrm{C}_{1}} * 100
$$

where, $\mathrm{SDI}=$ spatial dependency index; $\mathrm{C}_{0}=$ nugget effect; $\mathrm{C}_{1}=$ contribution; $\mathrm{C}_{0}+\mathrm{C}_{1}=$ sill.

For the attributes that presented spatial dependency among the sample data, the data interpolations were performed, and the thematic maps were built through the methods of inverse of the distance (ID), inverse of the square distance (ISD), and ordinary kriging. The evaluation of the concordance among maps was performed by means of matrices of errors used for the calculus of Kappa and Tau indices, and the scale proposed by Landis and Koch (1977), was used for its classification. Another index was also used for the map comparison: the relative deviation coefficient - RDC, Equation 2 (COELHO et al., 2009), which shows the average difference, in modulus, of the interpolated values of a thematic map as compared to a reference map.

$$
R D C=\sum_{i=1}^{M}\left|\frac{\hat{Z}_{i j}-\hat{Z}_{i}^{*}}{\hat{Z}_{i}^{*}}\right| \frac{100}{M}
$$

where, $\hat{Z}_{i}^{*}=$ estimated reference value at the location $i$ on the reference map; $\hat{Z}_{i j}=$ value at location $\mathrm{i}$ on the map to be compared; $M=$ total number of interpolated locations on the yield maps. 
The three methods of interpolation were also compared by the mean error (ME) and standard deviation of the means errors (SDME) parameters, obtained through the crossed validation. The $\mathrm{ME}$ value closer to zero and the smaller value of SDME were the criteria used to define the method of interpolation that presented, respectively, less biased results and results with less dispersion among the sampled data and the interpolated ones, showing so, better adjustment.

The measurement of central tendency (mean and median) was similar for a great part of the studied attributes (Table 1). The attributes $\mathrm{C}$ and $\mathrm{pH}$ were classified as having low $\mathrm{CV}$ (homogeneity). The attributes yield, Fe, Mn, and $\mathrm{Ca}$ had medium CV. The attribute $\mathrm{Mg}$ was classified as having high $\mathrm{CV}$, and $\mathrm{Cu}$, and $\mathrm{K}$ had very high CV (Table 1). By means of the skewness and kurtosis coefficients, it was noticed that the yield, $\mathrm{Cu}, \mathrm{C}, \mathrm{pH}, \mathrm{Ca}$, and $\mathrm{K}$ presented themselves as symmetrical, and the other attributes (Fe, Mn, and $\mathrm{Mg}$ ) were classified as having positive skewness, indicating that they have a predominance of values below the arithmetical mean (Table 1). The kurtosis was classified as mesokurtic for the yield, $\mathrm{Mn}, \mathrm{C}, \mathrm{pH}, \mathrm{Ca}$ and $\mathrm{K}$; as platikurtic for $\mathrm{Cu}$; and as leptokurtic for the other attributes. However, it was determined that there were not enough reasons to transform the data.

Table 1. Descriptive statistics of soybean yield and of the soil chemical attributes.

\begin{tabular}{cccccccccc}
\hline Attribute & Minimum & Mean & Median & Maximum & Amplitude & SD & CV $(\%)$ & Skewness & Kurtosis \\
\hline Yield $\left(\mathrm{t} \mathrm{ha}^{-1}\right)$ & 2.30 & 3.24 & 3.24 & 4.64 & 2.34 & 0.52 & $16.1(\mathrm{~m})$ & $0.26(\mathrm{~s})$ & $-0.18(\mathrm{~km})$ \\
$\mathrm{Cu}\left(\mathrm{mg} \mathrm{dm}^{-3}\right)$ & 1.00 & 2.24 & 2.11 & 4.21 & 3.21 & 0.93 & $41.4(\mathrm{vh})$ & $0.34(\mathrm{~s})$ & $-0.97(\mathrm{kp})$ \\
$\mathrm{Fe}\left(\mathrm{mg} \mathrm{dm}^{-3}\right)$ & 14.00 & 18.40 & 18.00 & 30.00 & 16.00 & 2.85 & $15.5(\mathrm{~m})$ & $1.29(\mathrm{p})$ & $3.81(\mathrm{kl})$ \\
$\mathrm{Mn}\left(\mathrm{mg} \mathrm{dm}^{-3}\right)$ & 37.00 & 49.65 & 49.00 & 68.00 & 31.00 & 6.69 & $13.5(\mathrm{~m})$ & $0.69(\mathrm{p})$ & $0.83(\mathrm{~km})$ \\
$\mathrm{C}\left(\mathrm{g} \mathrm{dm}^{-3}\right)$ & 28.05 & 33.08 & 33.12 & 37.79 & 9.74 & 2.39 & $7.2(1)$ & $0.18(\mathrm{~s})$ & $-0.58(\mathrm{~km})$ \\
$\mathrm{pH}$ & 4.50 & 5.24 & 5.20 & 6.00 & 1.50 & 0.35 & $6.7(\mathrm{l})$ & $0.15(\mathrm{~s})$ & $-0.50(\mathrm{~km})$ \\
$\mathrm{Ca}\left(\mathrm{cmol}_{\mathrm{c}} \mathrm{dm}^{-3}\right)$ & 3.79 & 6.74 & 6.75 & 9.90 & 6.11 & 1.34 & $19.8(\mathrm{~m})$ & $0.06(\mathrm{~s})$ & $-0.36(\mathrm{~km})$ \\
$\mathrm{Mg}\left(\mathrm{cmol}_{\mathrm{c}} \mathrm{dm}^{-3}\right)$ & 1.44 & 2.22 & 2.12 & 3.82 & 2.38 & 0.54 & $24.2(\mathrm{~h})$ & $1.26(\mathrm{p})$ & $1.99(\mathrm{kl})$ \\
$\mathrm{K}\left(\mathrm{cmol}_{\mathrm{c}} \mathrm{dm}^{-3}\right)$ & 0.09 & 0.28 & 0.28 & 0.60 & 0.51 & 0.11 & $37.6(\mathrm{vh})$ & $0.56(\mathrm{~s})$ & $0.43(\mathrm{~km})$ \\
\hline
\end{tabular}

SD - Standard Deviation; CV - Coefficient of Variation: low (l); medium (m), high (h), very high (vh); Skewness: Symmetric (s); Positive skewness (p); Negative skewness (n); Kurtosis: Mesokurtic (km); Platikurtic (kp); Leptokurtic (kl).

The geostatistics and the crossed validation showed that the Gaussian model was selected as the best one for the yield, $\mathrm{C}$, and $\mathrm{K}$ (Table 2). The exponential model was chosen for the $\mathrm{Cu}, \mathrm{Fe}$, and $\mathrm{Mn}$ data. For the other attributes $(\mathrm{pH}, \mathrm{Ca}$, and $\mathrm{Mg}$ ), the selected model was the spherical one. The spatial dependency index (SDI) corresponded to a strong spatial dependency only for the $\mathrm{Cu}$ attribute, classifying it as a moderate spatial dependency for the yield, $\mathrm{C}, \mathrm{pH}, \mathrm{Mg}$, and $\mathrm{K}$ data. The attributes $\mathrm{Fe}, \mathrm{Mn}$, and $\mathrm{Ca}$ presented weak spatial dependency (Table 2), corroborating the results of Mondo et al. (2012) and Negreiros Neto et al. (2014). 
Table 2. Parameters of the semivariogram for the best adjusted models.

\begin{tabular}{ccccccc}
\hline Attribute & Model & $\mathrm{C}_{0}$ & $\mathrm{C}_{1}$ & $\mathrm{C}_{0}+\mathrm{C}_{1}$ & Range $(\mathrm{m})$ & SDI\% \\
\hline Yield & Gaussian & 0.210 & 0.086 & 0.297 & 397.0 & $71(\mathrm{~m})$ \\
$\mathrm{Cu}$ & Exponential & 0.081 & 0.647 & 0.728 & 397.0 & $11(\mathrm{~s})$ \\
$\mathrm{Fe}$ & Exponential & 5.745 & 0.053 & 5.798 & 397.0 & $99(\mathrm{w})$ \\
$\mathrm{Mn}$ & Exponential & 35.28 & 8.613 & 43.89 & 397.0 & $80(\mathrm{w})$ \\
$\mathrm{C}$ & Gaussian & 4.176 & 2.427 & 6.603 & 397.0 & $63(\mathrm{~m})$ \\
$\mathrm{pH}$ & Spherical & 0.076 & 0.046 & 0.122 & 97.3 & $62(\mathrm{~m})$ \\
$\mathrm{Ca}$ & Spherical & 1.556 & 0.300 & 1.856 & 341.0 & $84(\mathrm{w})$ \\
$\mathrm{Mg}$ & Spherical & 0.151 & 0.163 & 0.314 & 199.4 & $48(\mathrm{~m})$ \\
$\mathrm{K}$ & Gaussian & 0.008 & 0.004 & 0.012 & 397.0 & $69(\mathrm{~m})$ \\
\hline
\end{tabular}

$\mathrm{C}_{0}$ - Nugget Effect; $\mathrm{C}_{1}$ - Contribution; $\mathrm{C}_{0}+\mathrm{C}_{1}$ - sill; SDI\% - Spatial Dependency Index: weak (w), moderate (m) and strong (s).

The data were interpolated by the ISD, ID, and ordinary kriging methods, and thematic maps were constructed (Figure 2). Then, the influence of the interpolators was evaluated through the generated maps for each attribute. The maps for each attribute were classified in five classes of the same amplitude (same intervals), using the values of maximum and minimum obtained by ISD as a basis, because this method produced the minimum and the maximum values among the values obtained by all the interpolators.

Visually, it was noticed that by means of the three interpolators, the maps follow the same tendency for all the attributes, with small differences among them, evidenced by the used indices of concordance. Just as Omran (2012) remarked, the maps generated by kriging are smoother, because this method aims to express the directional bias that the data suggest, avoiding the "bulls eye" effect that occurs with the other methods. It was noticed that the kriging provided for the yield, Fe, Mn, and $\mathrm{K}$ was classified in two classes, the $\mathrm{Ca}$ in one class only, and the $\mathrm{C}$ in three classes (Figure 2). This homogeneity is of consequence to the mitigation that occurred in the interpolation process throughout this method.

The maps of the attributes $\mathrm{Cu}, \mathrm{pH}$, and $\mathrm{Mg}$ were classified in four or five classes, because they suffered the smallest effect of the interpolator in relation to the original data, reducing the amplitude value less. The interpolator ID provided the construction of maps with four or five classes for all the attributes (Figure 2), but, in the same way as the maps were interpolated by kriging, a softness in the interpolation process occurred.

The data estimated by the three interpolators were evaluated by means of the descriptive statistics and compared to the original data (Table 3), aiming to identify the influence of the interpolators related to maintaining the initial structure found in sampling. In this way, the variation of percentage referring to the measures of position, dispersion, and form, was calculated, along with the results found from the sampling data and the interpolation. For all the attributes, the ISD method was the one that interfered the least with the amplitude of data in SD and CV. Generically, it influenced the behavior of data the least, practically maintaining the original amplitude.

It was noticed that the amplitude of values was significantly modified, mainly for the kriging and ID methods (Table 3 ). The reduction of the amplitude is the result of the increment in the minimum values, and a reduction of the maximum, values, leading to the data softness. This fact also influenced the $\mathrm{SD}$ and $\mathrm{CV}$ that suffered a reduction. The smallest influences on the amplitude $(0.1 \%)$ were found for the $\mathrm{pH}$ in the maps generated by ISD, and the biggest influence was for $\mathrm{Fe}(-80.2 \%)$ by kriging. 
Figure 2. Thematic maps of the attributes interpolated by the inverse of the square distance (ISD), inverse of the distance (ID), and kriging (Kri).

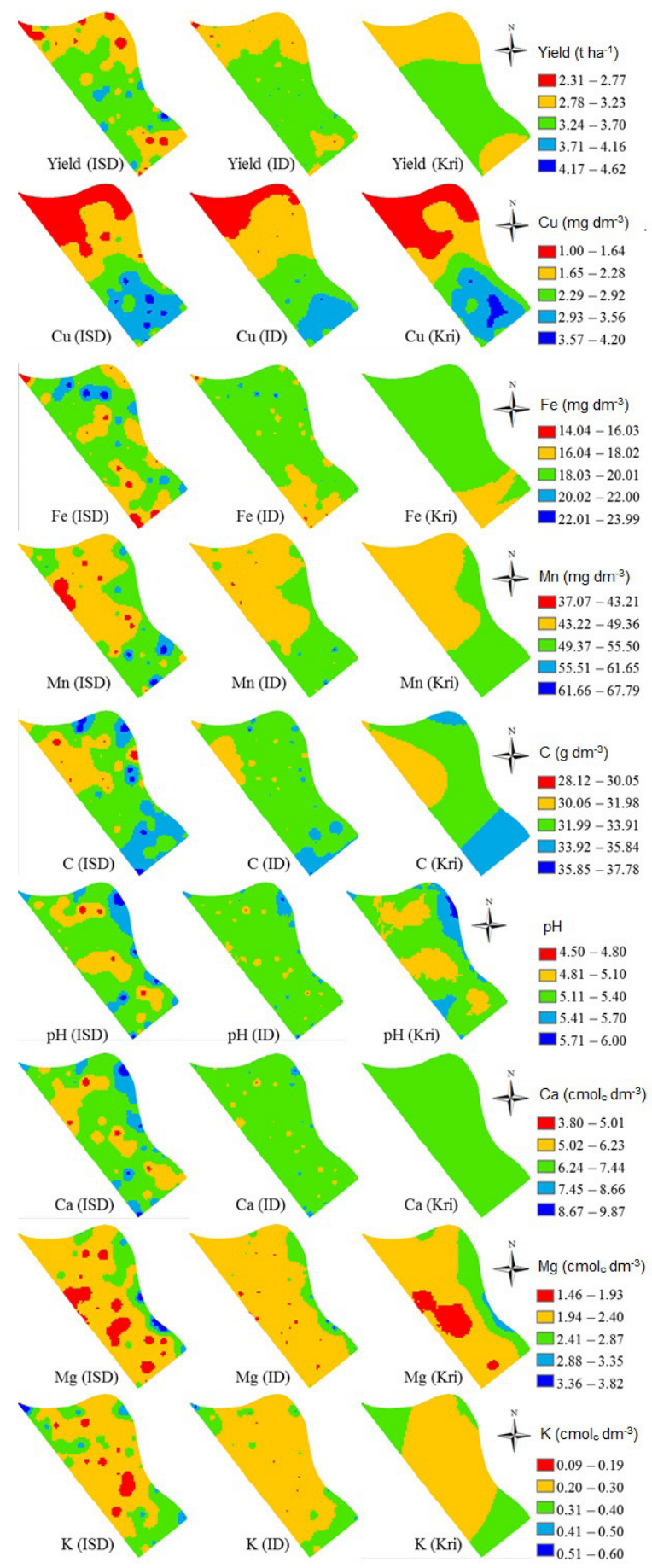

Generally, the kriging presented a greater influence at the increasing of the minimum value and at the reduction of the maximum value when comparing the interpolated values to the original values (Table 3), corroborating the results of Xie et al. (2011). However, the kriging was the method that influenced the mean and median the least. 
The resulting interpolation data by kriging, when compared to the values obtained by ISD presented, by the kappa index, strong or moderate concordance in the majority of the attributes, considering that only $\mathrm{Ca}$ presented weak concordance (Table 4).
The index of concordance, Tau, was classified as moderate for the $\mathrm{pH}$ and strong for the other attributes. In addition, by means of RDC, it was possible to identify that the difference among maps ranged from $1.3 \%$ to $8.1 \%$. Furthermore, the inverse behavior of RDC, Kappa, and Tau was clear.

Table 3. Effect of the interpolators on the sets of yield data and on the chemical attributes of the soil.

\begin{tabular}{|c|c|c|c|c|c|c|c|c|}
\hline Attribute & $\begin{array}{l}\text { Inter- } \\
\text { polator }\end{array}$ & $\begin{array}{l}\text { Variation } \\
\text { in the } \\
\text { minimum } \\
\text { value }\end{array}$ & $\begin{array}{l}\text { Variation } \\
\text { in the } \\
\text { Mean }\end{array}$ & $\begin{array}{l}\text { Variation } \\
\text { in the } \\
\text { Median }\end{array}$ & $\begin{array}{l}\text { Variation } \\
\text { in the } \\
\text { maximum } \\
\text { value }\end{array}$ & $\begin{array}{l}\text { Variation } \\
\text { in SD }\end{array}$ & $\begin{array}{l}\text { Variation } \\
\text { in } \mathrm{CV}\end{array}$ & $\begin{array}{l}\text { Variation } \\
\text { in } \\
\text { Amplitude }\end{array}$ \\
\hline \multirow{3}{*}{ Yield } & ISD & $0.3 \%$ & $1.2 \%$ & $2.4 \%$ & $-0.5 \%$ & $-53.8 \%$ & $-54.4 \%$ & $-1.2 \%$ \\
\hline & ID & $8.8 \%$ & $1.4 \%$ & $1.9 \%$ & $-11.5 \%$ & $-72.9 \%$ & $-73.3 \%$ & $-31.4 \%$ \\
\hline & Kri & $22.5 \%$ & $1.0 \%$ & $2.0 \%$ & $-16.5 \%$ & $-63.6 \%$ & $-64.0 \%$ & $-54.9 \%$ \\
\hline \multirow{3}{*}{$\mathrm{Cu}$} & ISD & $0.1 \%$ & $-1.5 \%$ & $2.6 \%$ & $-0.2 \%$ & $-31.0 \%$ & $-30.0 \%$ & $-0.3 \%$ \\
\hline & ID & $8.6 \%$ & $0.0 \%$ & $6.1 \%$ & $-9.5 \%$ & $-43.3 \%$ & $-43.3 \%$ & $-15.2 \%$ \\
\hline & Kri & $3.8 \%$ & $-6.9 \%$ & $-5.2 \%$ & $-7.4 \%$ & $-32.7 \%$ & $-27.7 \%$ & $-10.9 \%$ \\
\hline \multirow{3}{*}{$\mathrm{Fe}$} & ISD & $0.3 \%$ & $-0.2 \%$ & $1.5 \%$ & $-0.1 \%$ & $-60.3 \%$ & $-60.3 \%$ & $-0.6 \%$ \\
\hline & ID & $8.7 \%$ & $0.1 \%$ & $1.9 \%$ & $-4.7 \%$ & $-79.3 \%$ & $-79.3 \%$ & $-23.5 \%$ \\
\hline & Kri & $21.4 \%$ & $0.1 \%$ & $2.1 \%$ & $-20.9 \%$ & $-86.6 \%$ & $-86.6 \%$ & $-80.2 \%$ \\
\hline \multirow{3}{*}{$\mathrm{Mn}$} & ISD & $0.2 \%$ & $-0.7 \%$ & $1.0 \%$ & $-0.3 \%$ & $-53.1 \%$ & $-52.7 \%$ & $-0.9 \%$ \\
\hline & ID & $8.9 \%$ & $-0.9 \%$ & $0.1 \%$ & $-9.1 \%$ & $-71.3 \%$ & $-71.0 \%$ & $-30.5 \%$ \\
\hline & Kri & $20.5 \%$ & $-0.8 \%$ & $0.0 \%$ & $-20.9 \%$ & $-71.0 \%$ & $-70.7 \%$ & $-70.4 \%$ \\
\hline \multirow{3}{*}{$\mathrm{C}$} & ISD & $0.2 \%$ & $-0.6 \%$ & $-0.4 \%$ & $0.0 \%$ & $-52.1 \%$ & $-51.8 \%$ & $-0.9 \%$ \\
\hline & ID & $7.4 \%$ & $-0.5 \%$ & $-0.4 \%$ & $-2.0 \%$ & $-70.3 \%$ & $-70.1 \%$ & $-29.2 \%$ \\
\hline & Kri & $10.0 \%$ & $-0.5 \%$ & $0.1 \%$ & $-7.7 \%$ & $-56.5 \%$ & $-56.3 \%$ & $-58.8 \%$ \\
\hline \multirow{3}{*}{$\mathrm{pH}$} & ISD & $0.0 \%$ & $0.9 \%$ & $0.9 \%$ & $0.0 \%$ & $-41.7 \%$ & $-42.2 \%$ & $-0.1 \%$ \\
\hline & ID & $3.1 \%$ & $0.5 \%$ & $0.6 \%$ & $0.0 \%$ & $-54.2 \%$ & $-54.5 \%$ & $-9.2 \%$ \\
\hline & Kri & $9.0 \%$ & $1.9 \%$ & $1.9 \%$ & $0.0 \%$ & $-26.1 \%$ & $-27.4 \%$ & $-26.9 \%$ \\
\hline \multirow{3}{*}{$\mathrm{Ca}$} & ISD & $0.2 \%$ & $0.2 \%$ & $-0.7 \%$ & $-0.3 \%$ & $-52.8 \%$ & $-52.9 \%$ & $-0.6 \%$ \\
\hline & ID & $16.3 \%$ & $-0.6 \%$ & $-0.9 \%$ & $-10.7 \%$ & $-73.5 \%$ & $-73.3 \%$ & $-27.4 \%$ \\
\hline & Kri & $26.4 \%$ & $0.0 \%$ & $-0.5 \%$ & $-17.6 \%$ & $-73.0 \%$ & $-73.1 \%$ & $-44.9 \%$ \\
\hline \multirow{3}{*}{$\mathrm{Mg}$} & ISD & $1.2 \%$ & $1.0 \%$ & $0.2 \%$ & $0.0 \%$ & $-31.6 \%$ & $-32.3 \%$ & $-0.7 \%$ \\
\hline & ID & $18.4 \%$ & $0.3 \%$ & $1.0 \%$ & $-0.9 \%$ & $-44.1 \%$ & $-44.2 \%$ & $-12.6 \%$ \\
\hline & Kri & $24.4 \%$ & $2.3 \%$ & $1.3 \%$ & $-1.0 \%$ & $-30.1 \%$ & $-31.6 \%$ & $-16.4 \%$ \\
\hline \multirow{3}{*}{ K } & ISD & $4.4 \%$ & $-1.1 \%$ & $-1.4 \%$ & $-0.5 \%$ & $-55.6 \%$ & $-55.1 \%$ & $-1.4 \%$ \\
\hline & ID & $62.6 \%$ & $-3.3 \%$ & $-3.1 \%$ & $-13.9 \%$ & $-78.2 \%$ & $-77.5 \%$ & $-27.4 \%$ \\
\hline & Kri & $139.2 \%$ & $2.0 \%$ & $2.9 \%$ & $-38.1 \%$ & $-67.7 \%$ & $-68.3 \%$ & $-69.4 \%$ \\
\hline
\end{tabular}

SD - Standard Deviation; CV - Coefficient of Variation; Inverse of the square distance (ISD), inverse of the distance (ID) and kriging (Kri). 
Generically, the maps of all attributes, built by the three methods of interpolation, were classified as similar by means of the three indices used (Kappa and Tau were greater, RDC was smaller). The exception was the attribute $\mathrm{C}$, in which the RDC differed from the other indices, but with a small percentage difference between kriging vs. ISD and ISD vs. ID. It was noticed that kriging and ISD were the methods that provided maps with less concordance, but it does not mean that they are the worst interpolators.

Considering the closer ME (mean error) is to zero, the less biased are the results, kriging presented the best results for five attributes $(\mathrm{Cu}, \mathrm{Fe}, \mathrm{C}, \mathrm{Ca}$, and $\mathrm{K}$ ), the ISD for three attributes (yield, Mn and $\mathrm{Mg})$, and ID for one attribute $(\mathrm{pH})$ (Table 5). These results corroborate Yasrebi et al. (2009) and Reza et al. (2010), who analyzed soil properties and had, in most cases, smaller MEs using kriging.

Table 4. Comparison of maps generated by different interpolators by means of accuracy indices of Kappa, Tau, and RDC.

\begin{tabular}{|c|c|c|c|c|}
\hline Attribute & Interpolators & Kappa & Tau & $\mathrm{RDC}$ \\
\hline \multirow{3}{*}{ Yield } & kriging vs ISD & $0.69(\mathrm{~S})$ & $0.80(\mathrm{~S})$ & $2.8 \%$ \\
\hline & kriging vs ID & $0.72(\mathrm{~S})$ & $0.84(\mathrm{VS})$ & $2.2 \%$ \\
\hline & ISD vs ID & $0.66(\mathrm{~S})$ & $0.80(\mathrm{~S})$ & $2.7 \%$ \\
\hline \multirow{3}{*}{$\mathrm{Cu}$} & kriging vs ISD & $0.68(\mathrm{~S})$ & $0.70(\mathrm{~S})$ & $7.9 \%$ \\
\hline & kriging vs ID & $0.54(\mathrm{M})$ & $0.59(\mathrm{M})$ & $12.5 \%$ \\
\hline & ISD vs ID & $0.75(\mathrm{~S})$ & $0.78(\mathrm{~S})$ & $6.3 \%$ \\
\hline \multirow{3}{*}{$\mathrm{Fe}$} & kriging vs ISD & $0.47(\mathrm{M})$ & $0.69(\mathrm{~S})$ & $3.0 \%$ \\
\hline & kriging vs ID & $0.77(\mathrm{~S})$ & 0.89 (VS) & $1.1 \%$ \\
\hline & ISD vs ID & $0.62(\mathrm{~S})$ & $0.78(\mathrm{~S})$ & $2.0 \%$ \\
\hline \multirow{3}{*}{$\mathrm{Mn}$} & kriging vs ISD & $0.70(\mathrm{~S})$ & $0.80(\mathrm{~S})$ & $2.3 \%$ \\
\hline & kriging vs ID & $0.87(\mathrm{VS})$ & $0.92(\mathrm{VS})$ & $0.7 \%$ \\
\hline & ISD vs ID & $0.71(\mathrm{~S})$ & $0.81(\mathrm{VS})$ & $2.2 \%$ \\
\hline \multirow{3}{*}{$\mathrm{C}$} & kriging vs ISD & $0.65(\mathrm{~S})$ & $0.74(\mathrm{~S})$ & $1.3 \%$ \\
\hline & kriging vs ID & $0.48(\mathrm{M})$ & $0.67(\mathrm{~S})$ & $1.3 \%$ \\
\hline & ISD vs ID & $0.51(\mathrm{M})$ & $0.69(\mathrm{~S})$ & $1.1 \%$ \\
\hline \multirow{3}{*}{$\mathrm{pH}$} & kriging vs ISD & $0.47(\mathrm{M})$ & $0.57(\mathrm{M})$ & $1.8 \%$ \\
\hline & kriging vs ID & $0.32(\mathrm{~W})$ & $0.47(\mathrm{M})$ & $2.1 \%$ \\
\hline & ISD vs ID & $0.60(\mathrm{M})$ & $0.75(\mathrm{~S})$ & $1.0 \%$ \\
\hline \multirow{3}{*}{$\mathrm{Ca}$} & kriging vs ISD & $0.23(\mathrm{~W})$ & $0.65(\mathrm{~S})$ & $3.7 \%$ \\
\hline & kriging vs ID & $0.79(\mathrm{~S})$ & $0.96(\mathrm{VS})$ & $1.4 \%$ \\
\hline & ISD vs ID & $0.30(\mathrm{~W})$ & $0.67(\mathrm{~S})$ & $3.5 \%$ \\
\hline \multirow{3}{*}{$\mathrm{Mg}$} & kriging vs ISD & $0.63(\mathrm{~S})$ & $0.74(\mathrm{~S})$ & $4.2 \%$ \\
\hline & kriging vs ID & $0.55(\mathrm{M})$ & $0.70(\mathrm{~S})$ & $4.4 \%$ \\
\hline & ISD vs ID & $0.72(\mathrm{~S})$ & $0.82(\mathrm{VS})$ & $3.0 \%$ \\
\hline \multirow{3}{*}{$\mathrm{K}$} & kriging vs ISD & $0.43(\mathrm{M})$ & $0.65(\mathrm{~S})$ & $8.1 \%$ \\
\hline & kriging vs ID & $0.37(\mathrm{~W})$ & $0.64(\mathrm{~S})$ & $7.2 \%$ \\
\hline & ISD vs ID & $0.52(\mathrm{M})$ & $0.77(\mathrm{~S})$ & $6.2 \%$ \\
\hline
\end{tabular}

Concordance: weak (W); moderate (M); strong (S); very strong (VS). Best results are shaded. 
Table 5. Values of parameter ME (mean error) of crossed validation, referring to the data obtained by means of interpolators inverse of the distance (ID), inverse of the square distance (ISD), and ordinary kriging.

\begin{tabular}{cccccccccc}
\hline Interpolator & Yield & $\mathrm{Cu}$ & $\mathrm{Fe}$ & $\mathrm{Mn}$ & $\mathrm{C}$ & $\mathrm{pH}$ & $\mathrm{Ca}$ & $\mathrm{Mg}$ & $\mathrm{K}$ \\
\hline ID & 0.0270 & 0.039 & 0.085 & -0.166 & -0.047 & -0.030 & -0.069 & -0.034 & -0.010 \\
ISD & 0.0128 & 0.051 & 0.095 & -0.051 & 0.051 & -0.036 & -0.067 & -0.033 & -0.011 \\
Kriging & 0.0135 & 0.015 & 0.059 & -0.133 & -0.027 & -0.035 & -0.042 & -0.035 & -0.005 \\
\hline
\end{tabular}

Best results are shaded.

Similarly, the smaller the SDME (standard deviation of the means errors), the more efficient the interpolator. Kriging generated better results for five attributes (yield, $\mathrm{Cu}, \mathrm{Fe}, \mathrm{Mn}$, and $\mathrm{K}$ ), the ISD for four attributes $(\mathrm{C}, \mathrm{pH}, \mathrm{Ca}$, and $\mathrm{Mg})$, and the ID for none of them (Table 6), also corroborating the results of Yasrebi et al. (2009) and Reza et al. (2010). However, it was not possible to identify which method presented the best adjustment, because variations from one attribute to another, in relation to the distribution of spatial data, occurred. But kriging and ISD showed the best results, corroborating the results of Sajid et al. (2013).
However, the ME may present inconsistent results by considering in its calculation only the sum of the difference between the estimated value and sampled, so the SDME tends to be more consistent because it takes into consideration how the estimated value deviates from the average. Because this study used only sample data of yield and soil chemical properties, it is possible to identify the attributes classified as macronutrients tend to have lower SDME when used kriging, thus becoming the preferred method for interpolation. Similarly, for the micronutrient most appropriate method was considered the ISD.

Table 6. Values of parameter SDME (standard deviation of the means errors) of crossed validation referring to the data obtained by means of interpolators inverse of the distance (ID), inverse of the square distance (ISD), and ordinary kriging.

\begin{tabular}{cccccccccc}
\hline Interpolator & Yield & $\mathrm{Cu}$ & $\mathrm{Fe}$ & $\mathrm{Mn}$ & $\mathrm{C}$ & $\mathrm{pH}$ & $\mathrm{Ca}$ & $\mathrm{Mg}$ & $\mathrm{K}$ \\
\hline ID & 0.52 & 0.58 & 2.52 & 6.44 & 2.25 & 0.36 & 1.34 & 0.51 & 0.11 \\
ISD & 0.54 & 0.55 & 2.60 & 6.49 & 2.21 & 0.36 & 1.32 & 0.49 & 0.11 \\
Kriging & 0.51 & 0.55 & 2.49 & 6.40 & 2.24 & 0.39 & 1.33 & 0.79 & 0.10 \\
\hline
\end{tabular}

Best results are shaded.

The inverse of the square distance was the interpolator that influenced the data behavior the least, practically maintaining the original values. However, kriging was the method that presented the biggest influence, increasing the minimum value and reducing the maximum value when comparing the interpolated values to the original ones. The results indicate that kriging and inverse of the square distance proved to be the best interpolators, but the best one depends, mainly, on the attribute to be estimated.

\section{Acknowledgements}

The authors are grateful to the State University of Western Paraná (UNIOESTE), the Araucária Foundation (Fundação Araucária), the Coordination for the Improvement of Higher Education Personnel 
(CAPES), and the National Council for Scientific and Technological Development (CNPq), for the support received. They are also thankful to the engineer Agassiz Linhares Neto, for the cession of the area where the data used in this paper were collected.

\section{References}

AUBERT, B. A.; SCHROEDER, A.; GRIMAUDO, J. It as enabler of sustainable farming: An empirical analysis of farmers' adoption decision of precision agriculture technology. Decision Support Systems, Nottingham, v. 54, n. 1, p. 510-520, 2012.

BABAK, O.; DEUTSCH, C. V. Statistical approach to inverse distance interpolation. Stochastic Environmental Research and Risk Assessment, New York, v. 23, n. 1, p. 543-553, 2009.

CAMBARDELLA, C. A.; MOORMAN, T. B.; NOVAK, J. M.; PARKIN, T. B.; KARLEN, D. L.; TURCO, R. F.; KONOPKA, A. E. Field-scale variability of soil properties in central Iowa soils. Soil Science Society of America Journal, Madison, v. 58, n. 1, p. 1501-1511, 1994.

COELHO, E. C.; SOUZA, E. G. de; URIBE-OPAZO, M. A.; PINHEIRO NETO, R. Influência da densidade amostral e do tipo de interpolador na elaboração de mapas temáticos. Acta Scientiarum Agronomy, Maringá, v. 31, n. 1, p. 165-174, 2009.

COHEN, J. A coeficient of agreement for nominals scales. Journal of Education and Measurement, Durham, v. 20, n. 1, p. 37-46, 1960.

CORREAA, A. N.; TAVARES, M. H. F.; URIBE-OPAZO, M. A. Variabilidade espacial de atributos físicos do solo e seus efeitos sobre a produtividade do trigo. Semina: Ciências Agrárias, Londrina, v. 30, n. 1, p. 81-94, 2009.

DAVATGAR, N.; NEISHABOURI, M. R.; SEPASKHAH, A. R. Delineation of site specific nutrient management zones for a paddy cultivated area based on soil fertility using fuzzy clustering. Geoderma, Amsterdam, v. 173174, n. 1, p. 111-118, 2012.

DOERGE, T. A. Management zone concepts. SiteSpecific management guidelines. Norcross: Potash \& Phosphate Institute, 2000. 135 p.

FARIA, F. A.; PEDRONETTE, D. C. G.; SANTOS, J. A.; ROCHA, A.; TORRES, R. S. Rank Aggregation for pattern classi fi er selection in remote sensing images.
IEEE Journal of Selected Topics in Applied Earth Observations and Remote Sensing, Starkville, v. 7, n. 4, p. 1103-1115, 2014.

GUEDES, L. P. C.; URIBE-OPAZO, M. A.; RIBEIRO JUNIOR, P. J. Influence of incorporating geometric anisotropy on the construction of thematic maps of simulated data and chemical attributes of soi. Chilean Journal of Agricultural Research, Chillán, v. 73, n. 4, p. 414-423, 2013.

JOURNELL, A. G.; HUIJBREGTS, C. J. Mining geostaistics. London: Academic Press, 1978. 601 p.

LANDIS, J. R.; KOCH, G. G. The measurement of observer agreement for categorical data. Biometrics, Washington, v. 33, n. 1, p. 159-174, 1977.

MA, Z.; REDMOND, R. L. Tau coefficient for accuracy assessment of classification of remote sensing data. Photogrametric Engineering and Remote Sensing, Bethesda, v. 61, n. 4, p. 435-439, 1995.

MONDO, H. V. V.; GOMES JUNIOR, F. G.; PINTO, T. L. F.; MARCHI, J. L.; MOTOMIYA, A. V. A.; MOLIN, J. P.; CICERO, S. M. Spatial variability of soil fertility and its relationship with seed physiological potential in a soybean production area. Revista Brasileira de Sementes, Londrina, v. 34, n. 2, p. 193-201, 2012.

NEGREIROSNETO, J.V.; SANTOS,A.C.; GUARNIERI, A.; SOUZA, D. J. A. T.; DARONCH, D. J.; DOTTO, M. A.; ARAÚJO, A. S. Variabilidade espacial de atributos físico-químicos de um Latossolo Vermelho-Amarelo distrófico em sistema plantio direto Spatial variability of chemical and physical attributes of dystrophic RedYellow Latosol in no tillage. Semina:Ciencias Agrarias, Londrina, v. 35, n. 1, p. 193-204, 2014.

OMRAN, E. E. Improving the prediction accuracy of soil mapping through geostatistics. International Journal of Geosciences, Delaware, v. 3, n. 3, p. 574-590, 2012.

PIMENTEL-GOMES, F. Curso de estatística experimental. 15. ed. Piracicaba: FEALQ, 2009. 451 p.

REZA, S. K.; SARKAR, D.; DARUAH, U.; DAS, T. H. Evaluation and comparison of ordinary kriging and inverse distance weighting methods for prediction of spatial variability of some chemical parameters of Dhalai district, Tripura. Agropedology, Nagpurna, v. 20, n. 1, p. 38-48, 2010.

SAJID, A. H.; RUDRA, R. P.; PARKIN, G. Systematic evaluation of kriging and inverse distance weighting methods for spatial analysis of soil bulk density. Canadian Biosystems Engineering, Winnipeg, v. 55, n. 1983, p. 1-14, 2013. 
SANO, E. E.; SANTOS, E. M.; MENESES, P. R. Análise de imagens do satélite Alos Palsar para o mapeamento de uso e cobertura da terra do distrito federal. Geociências, São Paulo, v. 28, n. 4, p. 441-451, 2009.

SILVA NETO, S. P.; SANTOS, A. C.; LEITE, R. L. L.; DIM, V. P.; CRUZ, R. S.; PEDRICO, A.; NEVES NETO, D. N. Análise espacial de parâmetros da fertilidade do solo em região de ecótono sob diferentes usos e manejos. Semina: Ciencias Agrárias, Londrina, v. 32, n. 2, p. 541552, 2011.

SOUZA, C. H. W.; MERCANTE, E.; PRUDENTE, V. H. R.; JUSTINA, D. D. D. Methods of performance evaluation for the supervised classification of satellite imagery in determining land cover classes. Ciencia $e$ Investigacion Agraria, Santiago, v. 40, n. 2, p. 419-428, 2013.

SOUZA, E. G.; BAZZI, C. L.; KHOSLA, R.; URIBEOPAZO, M. A.; REICH, R. M. Interpolation type and data computation of crop yield maps is important for precision crop production. Journal of Plant Nutrition, Philadelphia, v. 39, n. 4, p. 531-538, 2016.
SUSZEK, G.; SOUZA, E. G. de; URIBE-OPAZO, M. A.; NOBREGA, L. H. P. Determination of management zones from normalized and standardized equivalent produtivity maps in the soybean culture. Engenharia Agrícola, Jaboticabal, v. 31, n. 5, p. 895-905, 2011.

WOLLENHAUPT, N. C.; WOLKOWSKI, R. P. Grid soil sampling. Better Crops With Plant Food, Norcross, v. 78, n. 4, p. 6-9, 1994.

XIE, Y.; CHEN, T.; LEI, M.; YANG, J.; GUO, Q.; SONG, B.; ZHOU, X. Spatial distribution of soil heavy metal pollution estimated by different interpolation methods: accuracy and uncertainty analysis. Chemosphere, Amsterdam, v. 82, n. 3, p. 468-476, 2011.

YASREBI, J.; SAFFARI, M.; FATHI, H.; KARIMIAN, N.; MOAZALLAHI, M.; GAZNI, R. Evaluation and comparison of ordinary kriging and inverse distance weighting methods for prediction of spatial variability of some soil chemical parameters. Research Journal of Biological Sciences, Brisbane, v. 4, n. 1, p. 93-102, 2009. 
